\title{
HUBUNGAN JENIS KELAMIN DAN GAMBARAN KLINIS CELAH BIBIR NON SINDROMIK DI CLP CENTER FK UMM
}

\author{
Ruby Riana Asparini (*), Erika Yuli Susanti (**), Gita Sekar Prihanti (*), \\ (*) Fakultas Kedokteran, Universitas Muhammadiyah Malang \\ (**) Program Studi Pendidikan Dokter, Fakultas Kedokteran, Universitas Muhammadiyah Malang \\ Pendidikan Dokter, Fakultas Kedokteran, Universitas Muhammadiyah Malang \\ Jl. Bendungan Sutami 188 A Malang, 65145 \\ rubyriana16@gmail.com \\ susantierika2@gmail.com \\ gitasekarprihanti@gmail.com
}

\begin{abstract}
Abstrak
Latar Belakang: Celah bibir non sindromik merupakan jenis celah yang tanpa disertai kelainan pada kepala dan leher. Terdapat perbedaan jenis kelamin terhadap waktu penutupan langit-langit. .

Tujuan: Mengetahui hubungan jenis kelamin dan gambaran klinis celah bibir (dengan atau tanpa celah langit-langit) non sindromik di CLP Center FK UMM (tahun 2016-2017).

Metode: Cross Sectional. Data jenis kelamin serta gambaran klinis celah bibir non sindromik yang diperoleh dari CLP Center FK UMM sebanyak 241 dari 271. Analisis data menggunakan uji chi-Squaredengan syarat expectedcountkurang dari lima tidak lebih dari $20 \%$. Jika tidak memenuhi syarat menggunakan uji non parametrikMann Whitney.

Hasil dan Diskusi: Hasil analisis data uji chi-Squaretidak memenuhi syarat sehingga dilakukan uji non parametrikMann Whitney yang menunjukkan $\mathrm{p}=0,152(\mathrm{p}>0,05)$, yang berarti tidak ada hubungan jenis kelamin dan gambaran klinis celah bibir (dengan atau tanpa celah langit-langit) non sindromik.
\end{abstract}

Kesimpulan: Tidak terdapat hubungan jenis kelamin dan gambaran klinis celah bibir (dengan atau tanpa celah langit-langit) non sindromik.

Kata kunci: Celah Bibir (CB), Celah Bibir dan Langit-langit (CBL), Non sindromik, Jenis Kelamin, Gambaran Klinis.

\section{Abstract}

Background: Non syndromic cleft lips the cleft type that not followed by any head and neck abnormalities. There is difference beetween sex and the time of palate fusion. Man's palate fusion a week earlier than woman.

Objective: Finding out the correlation of sex and clinical extension of non syndromic cleft lip at Medical FacultyofMuhammadiyah Malang University's CLP Center.

Method: Cross Sectional. The data of sex and clinical extension was obtained 241 of 271 from CLP Center. Data analysis using chi-Square test with expected count less than five not more than $20 \%$. If the term not ful filled the nusing non parametric test of Mann Whitney.

Resultanddiscussion: Data analysis using chi-Square was not ful filled the terms the nusing non parametrictestofMann Whitney, showed $\mathrm{p}=0,152$ ( $\mathrm{p}>0,05)$, which means there was no mean correlation between sex and clinical extension of non syndromic cleft lip.

Conclusion: No mean correlation between sex and clinical extension of non syndromic cleft lip (with or without cleft palate).

Keyword: Cleft Lip (CL), Cleft Lipand Palate(CLP), non syndromic, sex, clinicalextension. 


\section{PENDAHULUAN}

Celah bibir dengan atau tanpa celah langit-langit(CB/L) adalah suatu kelainan bawaan yang terjadi pada bibir bagian atas dengan atau tanpa disertai celah langit-langit lunak(palatummolle)dan langit-langit keras(palatum durum)rongga mulut. Celah bibir terjadi karena hipoplasia pada lapisan mesenkim, yang mengakibatkan kegagalan medial nasal dan proses maksila untuk bergabung. Mayo HealthBook menjelaskan beberapa faktor bisa terlibat sebagai predisposisi CB/L: geografi faktor, ras, riwayat keluarga, jenis kelamin, paparan faktor risiko selama kehamilan, seperti konsumsi alkohol dan merokok tembakau, gizi buruk, infeksi virus, obat-obatan dan juga teratogen di tempat kerja dan di rumah. Studi terakhir menunjukkan bahwa bahkan obesitas selama kehamilan mungkin berhubungan dengan bibir sumbing dan langit-langit mulut(1).

Celah bibir dengan atau tanpa celah langit-langit berdasarkan etiologidikategorikan menjadi sindromik dan non sindromik. Sekitar 70\% kasus CB/L adalah nonsindromik, yaitu apabila celah merupakan kondisi terisolasi yang tidak terkait dengan kelainan lain. 30\% sisanya merupakan kasus sindromik, terdapat kecacatan atau kelainan struktural yang terjadi di luar regio celah (2). Kejadian CB/L lebih sering pada lakilaki, dan celah langit-langit (CL) lebih sering pada perempuan, di berbagai kelompok etnis. Rasio jenis kelamin bervariasi dengan tingkat keparahan celah, adanya malformasi tambahan, jumlah saudara kandung yang terpengaruh dalam keluarga, asal etnis, dan kemungkinan usia ayah. Populasi kulit putih memiliki rasio jenis kelamin untuk $\mathrm{CB} / \mathrm{L}$ sekitar 2: 1 (laki-laki: perempuan) (3). $\mathrm{CB} / \mathrm{L}$ diketahui memiliki perbedaan rasio jenis kelamin yang konstan dan telah terbukti (4).

Celah unilateral lebih umum daripada bilateral pada $\mathrm{CB}$ dan $\mathrm{CB} / \mathrm{L}$. Frekuensi $\mathrm{CB} / \mathrm{L}$ bilateral secara signifikan lebih tinggi daripada CB bilateral. Selain itu, pasien dengan CB/L bilateral lebih sering mengalami deformitas nasal dan deformitas kedalaman nasofaring daripada CB/L unilateral. Keterlibatan langit-langit pada pasien dengan sumbing mulut berhubungan dengan gangguan struktur wajah dan saluran napas dan peningkatan risiko gangguan tidur dan pernapasan. CBL komplit secara signifikan lebih sering daripada CB atau CL komplit(5).

Langit-langit perempuan diketahui menutup satu minggu lebih lambat dari langitlangit laki-laki, pengamatan yang dapat menjelaskan mengapa CL lebih umum pada perempuan dari pada laki-laki. Seperti disebutkan di atas, CBL adalah presentasi yang paling umum dari celah orofacial. Celah bibir terjadi pada usia dini dalam perkembangan embriologis; diskontinuitas bibir ini menghasilkan obstruks imigrasi lidah yang sering mengganggu keselarasan horizontal dan fusi rakpalatum. Dengan demikian, celah bibir meningkatkan kemungkinan celah langit-langit berkembang(6).

Cleft Lipand Palate(CLP) Center Fakultas Kedokteran Universitas Muhammadiyah Malang (FK UMM) telah mengadakan kegiatan pengabdian masyarakat berupa operasi gratis celah bibir dan langit-langit sejak tahun 2008 dan 
telah menangani sekitar 2000 pasien. Pasien berasal dari Jawa Timur dan sekitarnya(7).

Berdasarkan uraian tersebut maka peneliti bermaksud untuk meneliti hubungan jenis kelamin dan gambaran klinis $\mathrm{CB} / \mathrm{L}$ NS di CLP Center FK UMM.

\section{METODE PENELITIAN}

Penelitian ini merupakan penelitian observasional analitik dengan metode Cross Sectional. Data penelitian di ambil di Cleft Lipand Palate (CLP) Center Fakultas Kedokteran Universitas Muhammadiyah Malang tahun 20162017. Sampel yang digunakan berjumlah 241 data dengan teknik pengambilan sampel yaitu total sampling. Prosedur penelitian ini diawali dengan pengambilan data sekunder yaitu rekam medis di CLP Center FK UMM tahun 2016-2017 dan dilanjutkan dengan penyeleksian kriteria inklusi. Kriteria inklusi pada penelitian ini adalah pasien $\mathrm{CB} / \mathrm{L} \mathrm{NS}$, terdapat foto pre-operasi dan terdapat nomer telepon orang tua/wali untuk mendapatkan informasi tambahan. Sampel yang sesuai kriteria inklusi selanjutnya dibedakan jenis kelamin laki-laki dan perempuan, kemudian mengkategorikan foto pre-operasi dengan empat kategori, yaitu unilateral komplit, unilateral inkomplit, bilateral komplit dan bilateral inkomplit. Kemudian melakukan analisis data dan membuat laporan hasil.

\section{HASIL PENELITIAN}

Diagram 1. Deskripsi berdasarkan tahun

Diagram 1 menunjukkan jumlah pasien tahun 2017 (75,52\%) lebih banyak dibandingkan pasien tahun $2016(24,48 \%)$. 


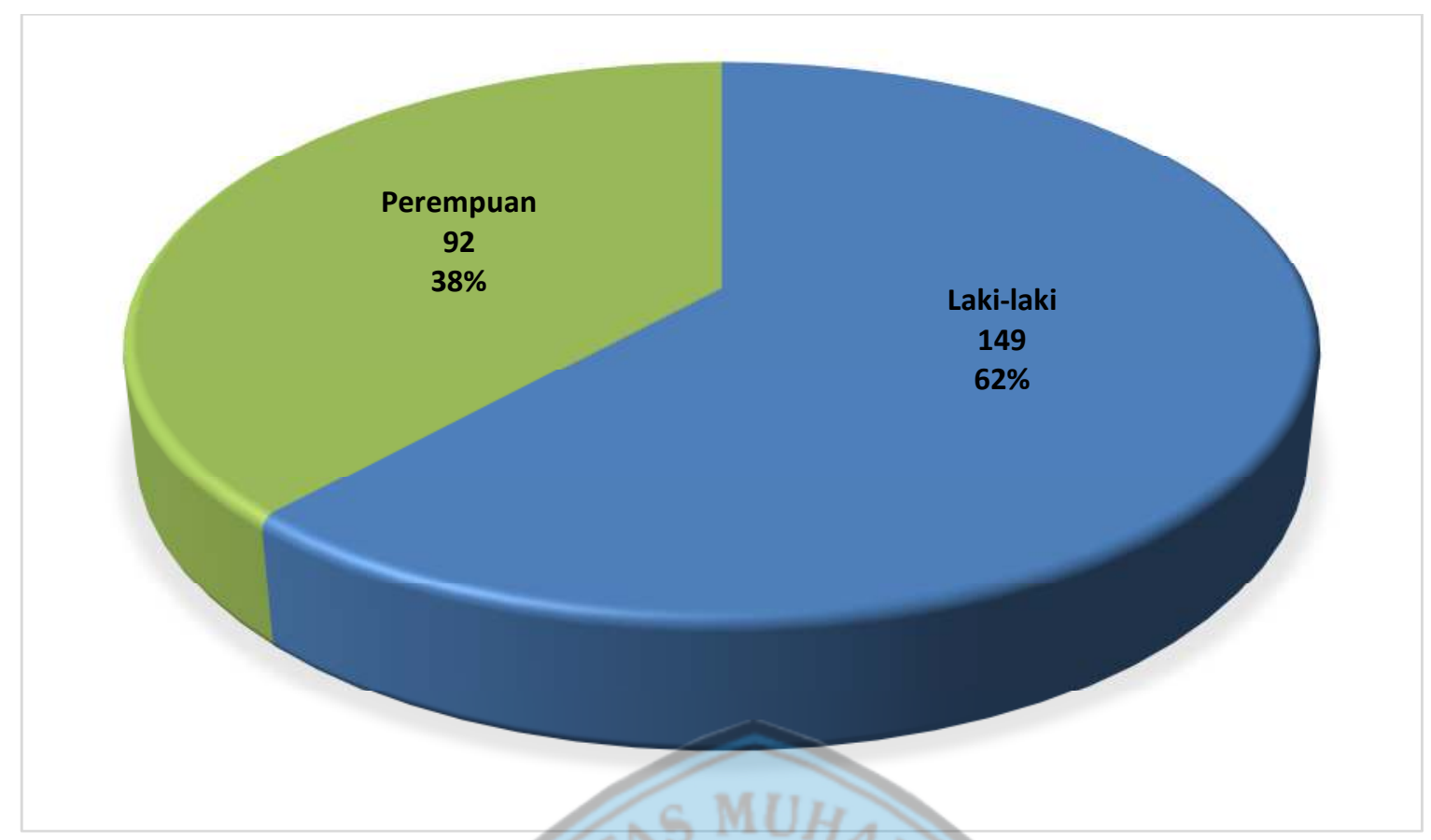

Diagram.2. Deskripsi jenis kelamin pasien

Diagram 2 menunjukkan jumlah pasien laki-laki (61,8\%) lebih banyak dibandingkan jumlah pasien perempuan $(38,2 \%)$.

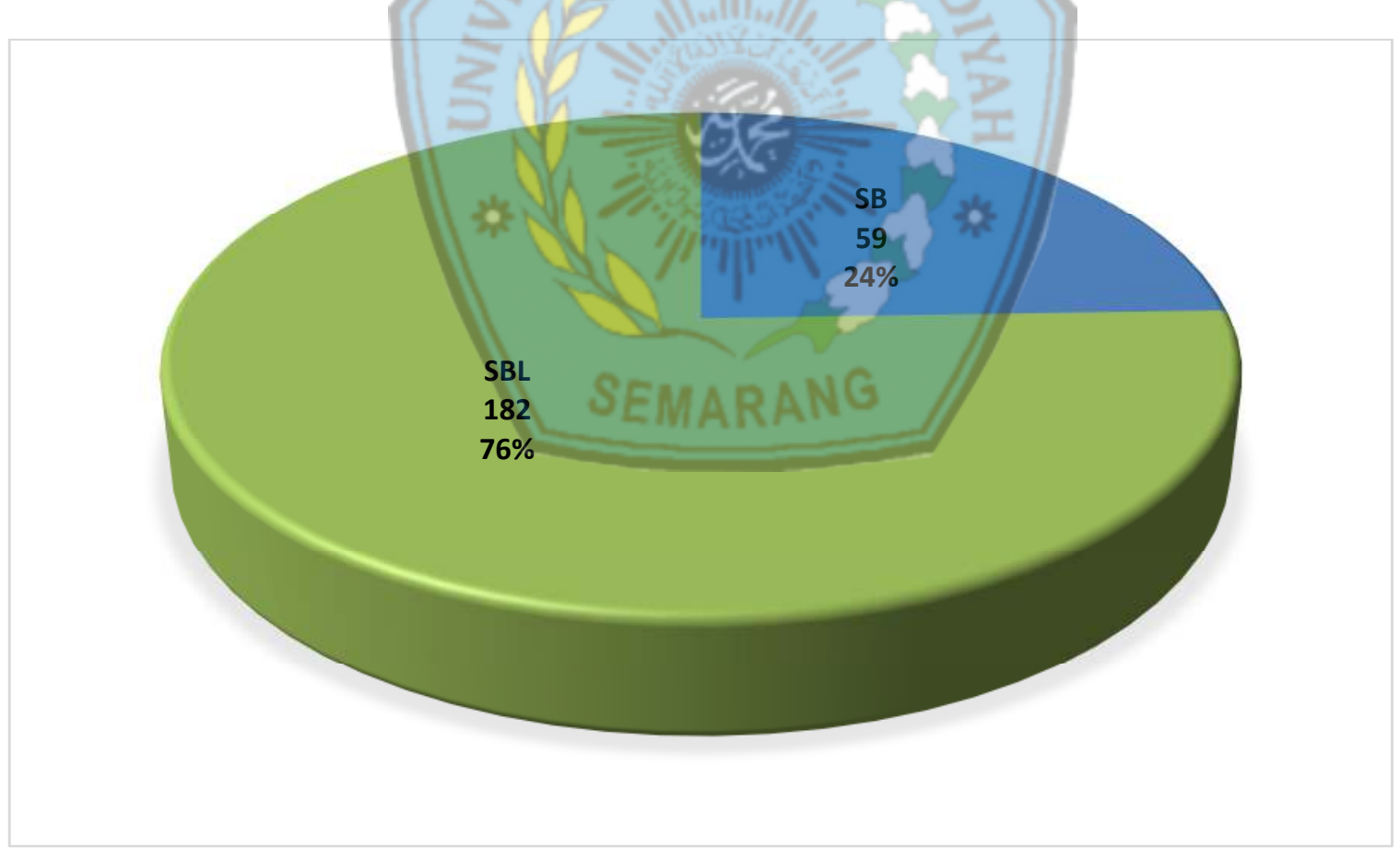

Diagram 3. Jenis celah bibir (dengan atau tanpa celah langit-langit) non sindromik

Diagram3 menunjukkan pasien CBL NS (75,5\%) lebih banyak daripada pasien CB NS (24,5\%) 


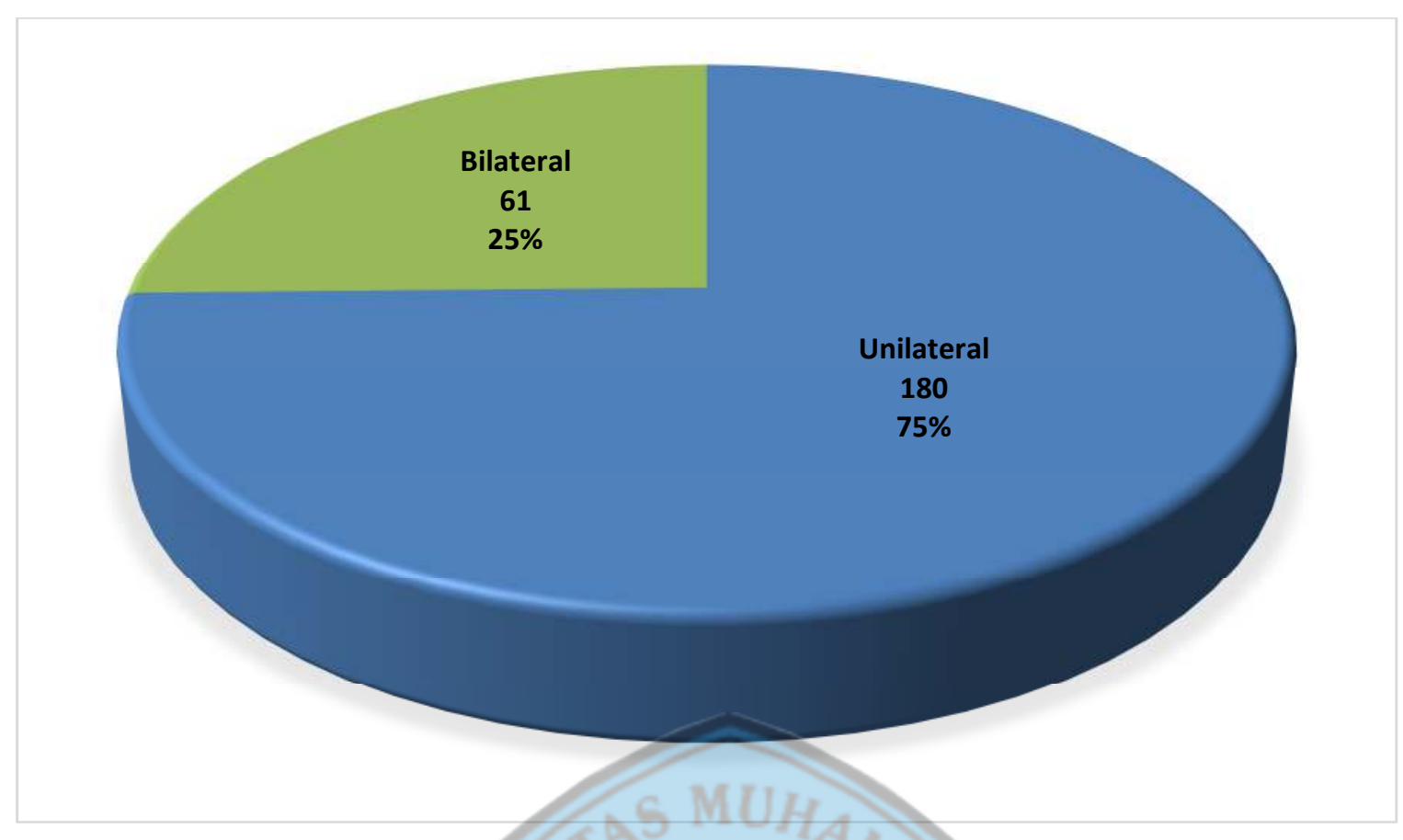

Diagram 4. Gambaran klinis menurut letak sisi celah

Diagram.4 menunjukkan gambaran klinis unilateral $(74,7 \%)$ lebih banyak dibandingkan bilateral $(25,3 \%)$.

Diagram 5. Distribusi gambaran klinis menurut lebar celah

Diagram.5 menunjukkan gambaran klinis komplit (87,5\%) dibandingkan inkomplit (12,5\%). 


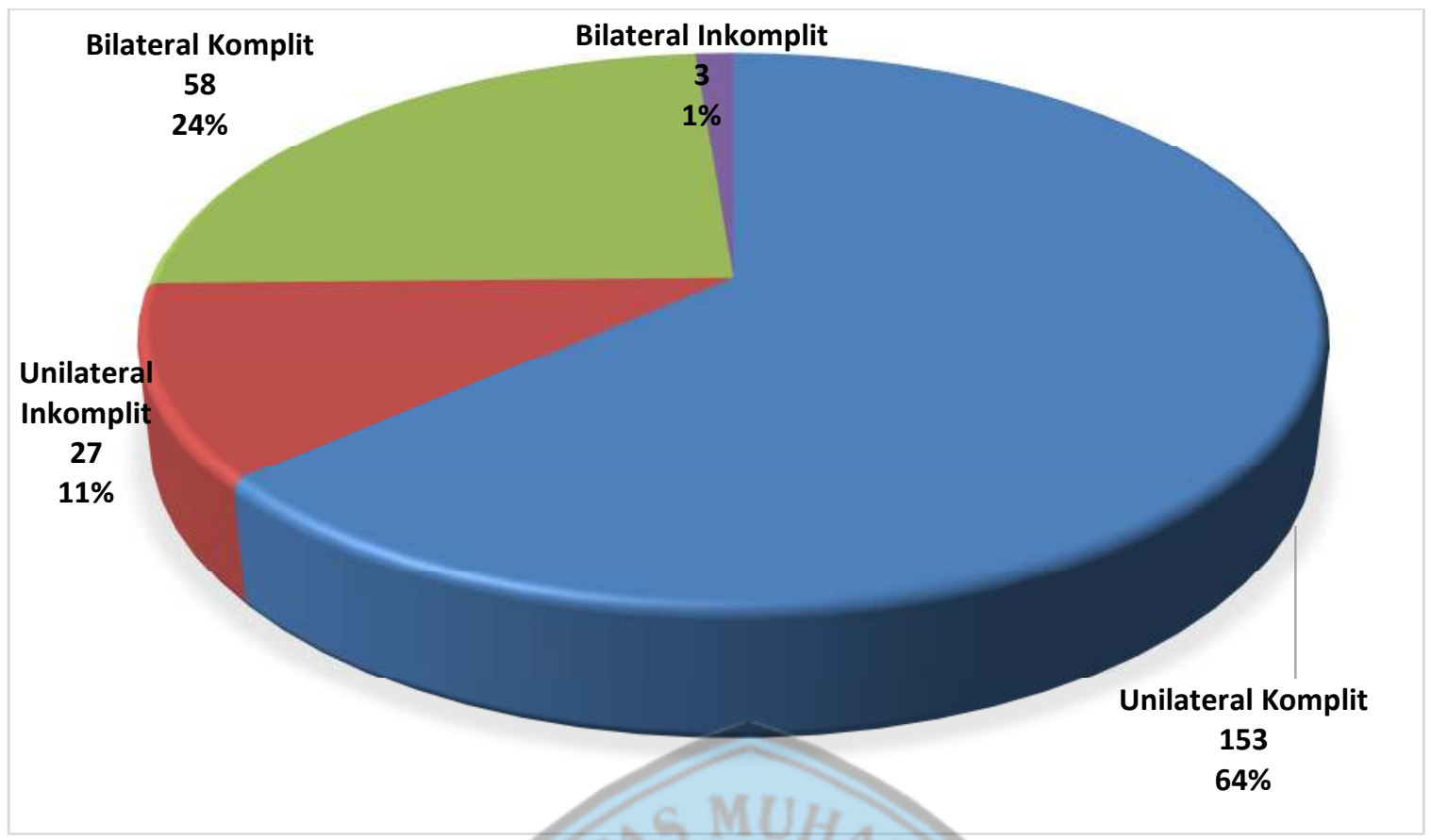

Diagram 6. Distribusigambaran klinis menurut letak sisi celah dan lebar celah

Diagram.6 menunjukkan gambaran klinis paling banyak yakni unilateral komplit (63,5\%) dan paling sedikit bilateral komplit $(1,2 \%)$.

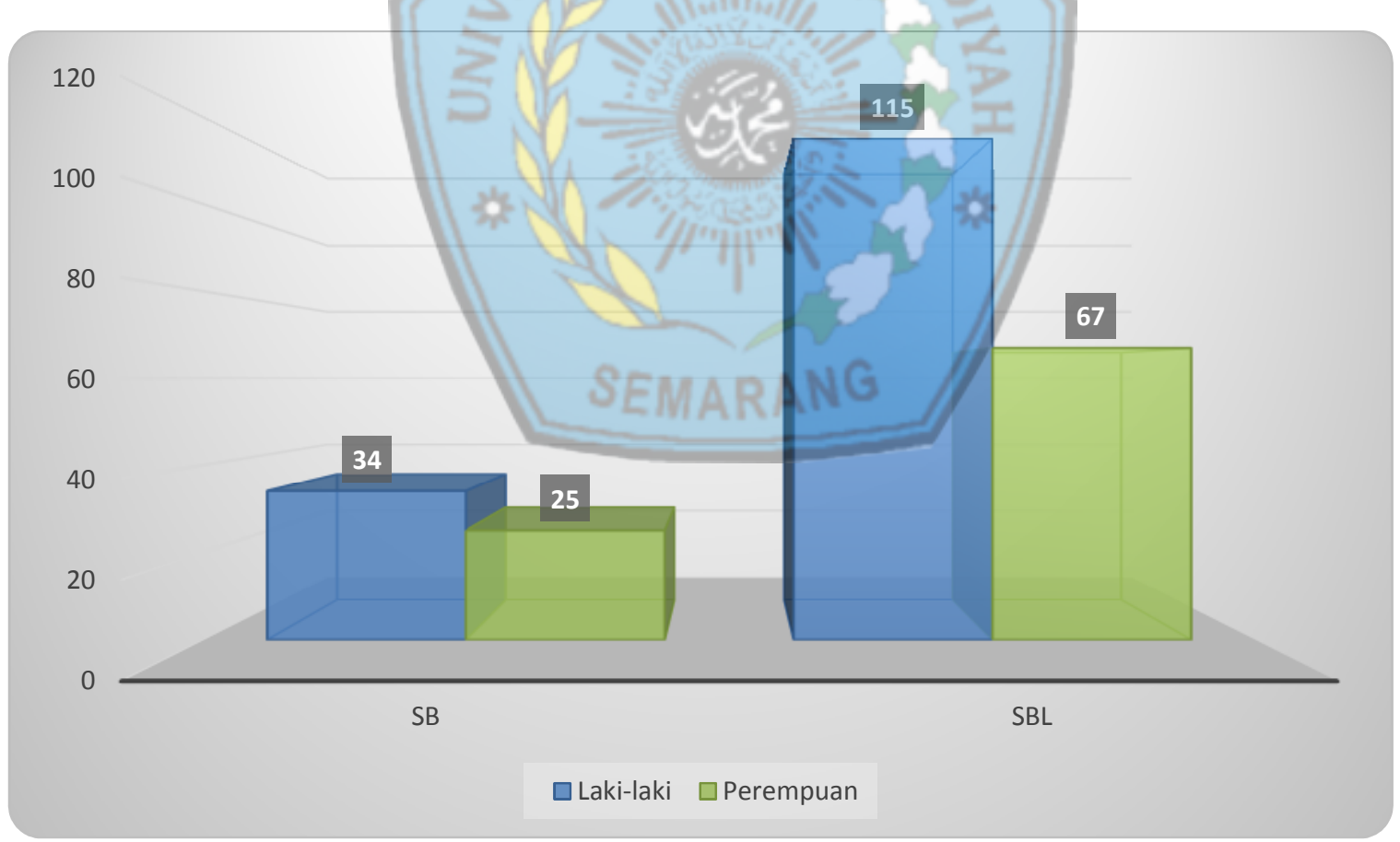

Diagram 7. Distribusi jenis kelamin terhadap jenis celah

Diagram 7 menunjukkan pasien CB NS laki-laki (57,6\%) lebih banyak dibandingkan perempuan (42,4\%). Pasien CBL NS laki-laki (63,2\%) lebih banyak dibandingkan perempuan (36,8\%). 


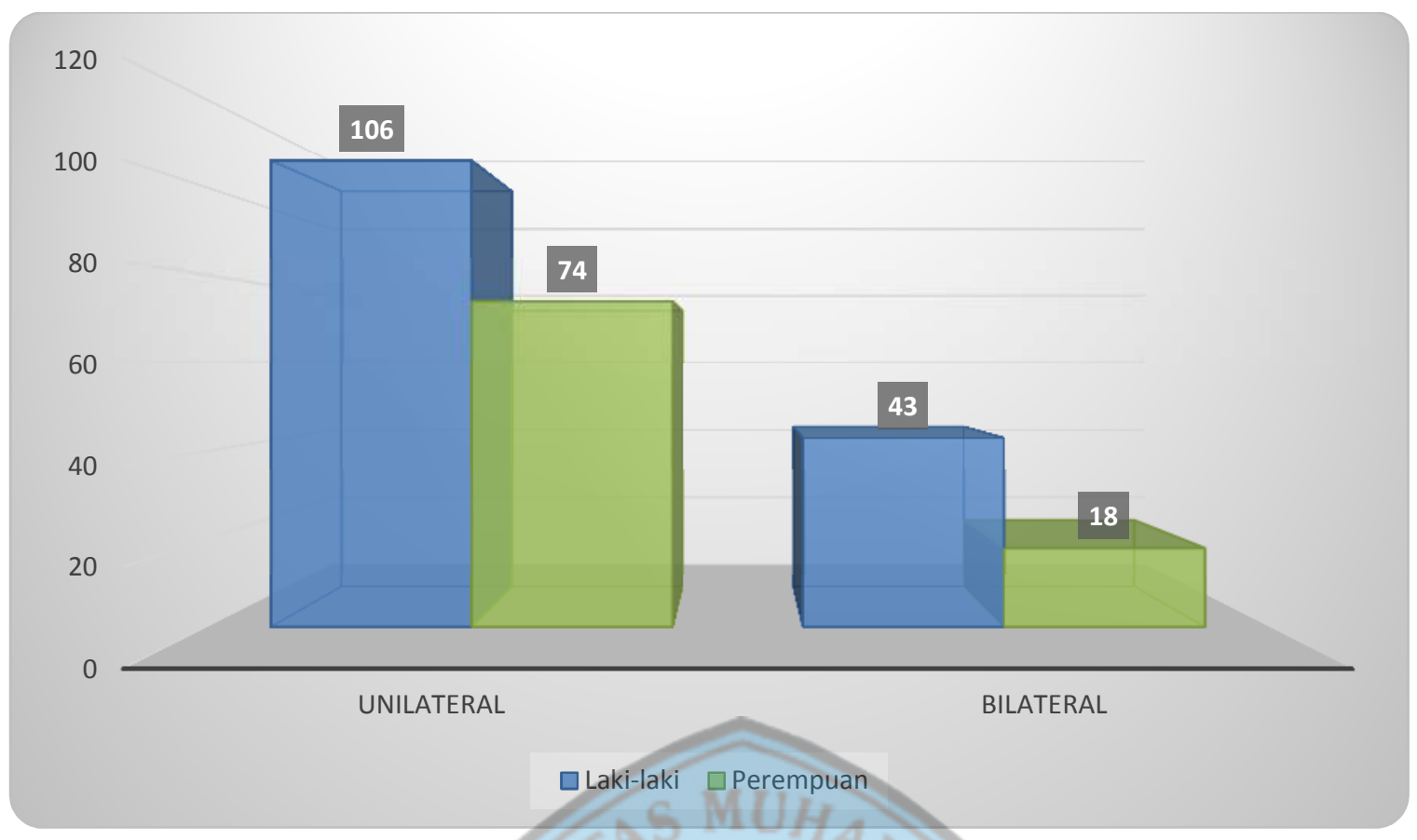

Diagram 8. Distribusi jenis kelamin terhadap gambaran klinis letak sisi celahnya

Diagram 8 menunjukkan gambaran klinis celah unilateral pada laki-laki (58,8\%) lebih banyak dibandingkan perempuan (41,2\%). Gambaran klinis celah bilateral pada laki-laki (70,4\%) lebih banyak dibandingkan perempuan $(29,6 \%)$.

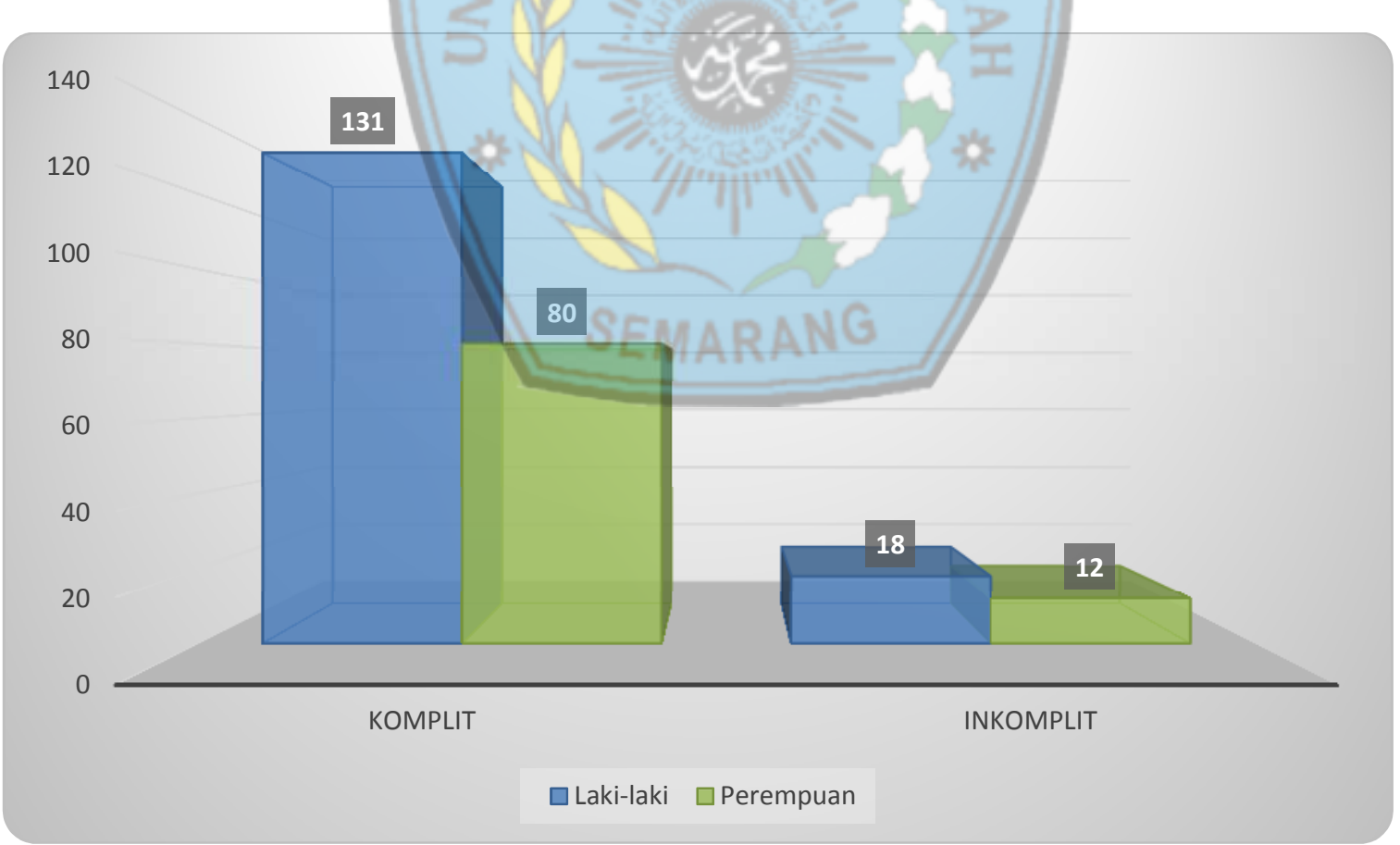

Diagram 9. Distribusi jenis kelamin menurut lebar celah

Diagram 9 menunjukkan bahwa gambaran klinis celah komplit pada laki-laki (62,1\%) lebih banyak dibandingkan perempuan $(37,9 \%)$. Gambaran klinis celahinkomplitpada laki-laki (60\%) lebih banyak dibandingkan perempuan $(40 \%)$. 
Tabel 1. Prevalensi jenis kelamin terhadap gambaran klinis menurut letak celahnya dan luas celahnya

\begin{tabular}{|c|c|c|c|c|c|}
\hline Jenis Kelamin & \multicolumn{4}{|c|}{ Gambaran Klinis } & $\mathrm{p}$-value \\
\hline & $\begin{array}{l}\text { Unilateral } \\
\text { Komplit }\end{array}$ & $\begin{array}{l}\text { Unilateral } \\
\text { Inkomplit }\end{array}$ & $\begin{array}{l}\text { Bilateral } \\
\text { Komplit }\end{array}$ & $\begin{array}{c}\text { Bilateral } \\
\text { Inkomplit }\end{array}$ & 0,152 \\
\hline Laki-laki & 90 & 16 & 41 & 2 & \\
\hline Perempuan & 63 & 11 & 17 & 1 & \\
\hline Total & 153 & 27 & 58 & 3 & \\
\hline
\end{tabular}

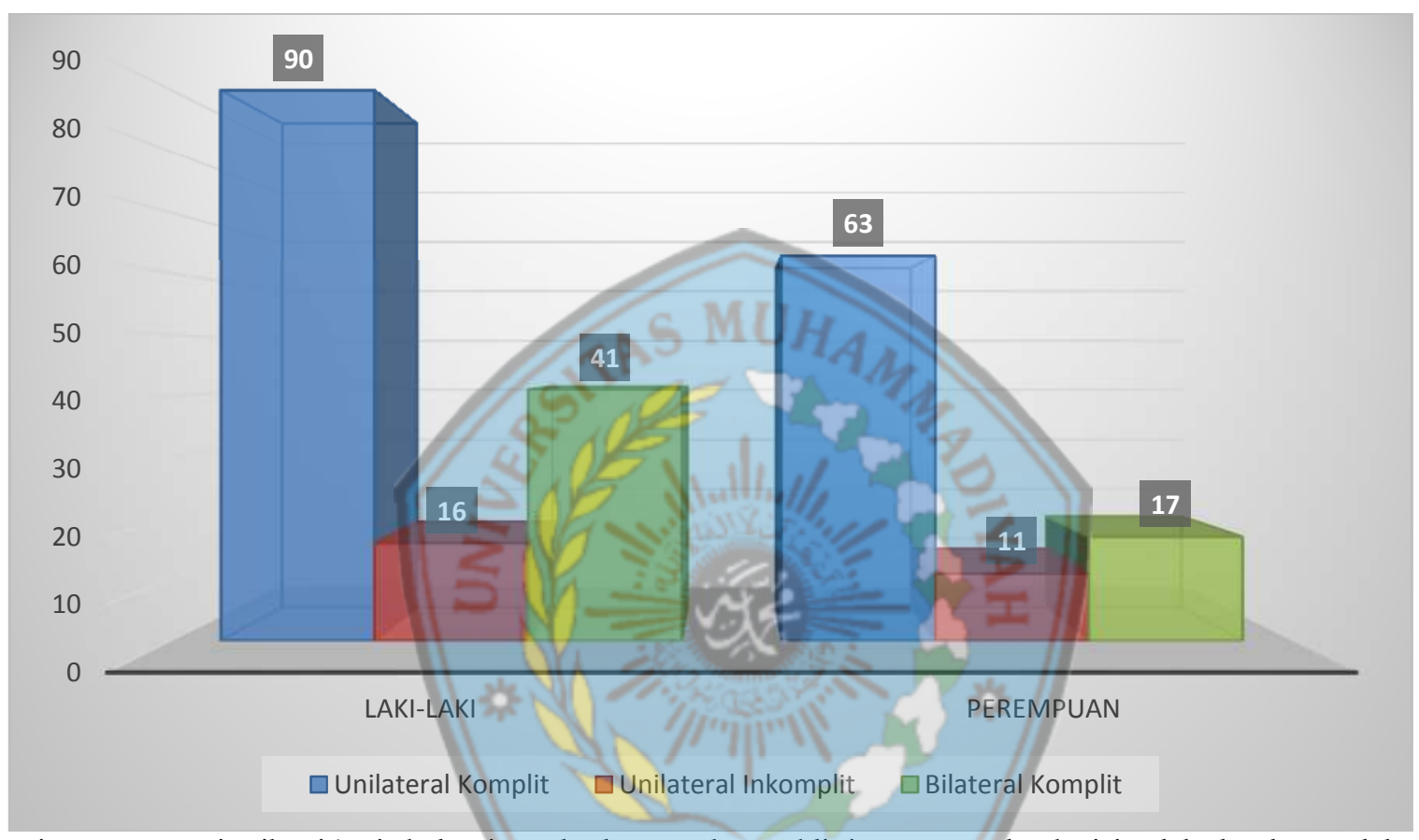

Diagram 10. Distribusi jenis kelamin terhadap gambaran klinis menurut letak sisi celah dan luas celah Diagram 10 menunjukkan bahwa gambaran klinis celah unilateral komplit pada laki-laki (58,8\%) lebih banyak dibandingkan perempuan $(41,2 \%)$. Gambaran klinis celah unilateral inkomplitpada laki-laki $(59,3 \%)$ lebih banyak dibandingkan perempuan (40,7\%). Gambaran klinis celah bilateral komplit pada laki-laki $(70,7 \%)$ lebih banyak dibandingkan perempuan (29,3\%). Gambaran klinis celah bilateral inkomplit pada laki-laki (66,7\%) lebih banyak dibandingkan perempuan (33.3\%).

Analisis data yang digunakan yakni uji chiSquare dengan syarat expectedcount kurang dari 5 tidak lebih dari 20\%. Hasil uji chisquaremenunjukkan bahwa expectedcount kurang dilakukan uji non parametrikMannWhitney. Analisis data menggunakan uji non parametrikMann-Whitney pada tabel 1 didapatkan hasil nilai signifikansi 0,152 ( $>>0,05)$ yang berarti data tidak signifikan. Hal ini dari 5 sebanyak 25\% yang berarti hasil uji chisquare tersebut tidak memenuhi syarat. Selanjutnya

menunjukkan bahwa tidak ada hubungan antara jenis kelamin dan gambaran klinis CB/L NS.

\section{PEMBAHASAN}


Hasil penelitian yang telah dilakukan menunjukkan tidak adanya hubungan jenis kelamin dan gambaran klinis CB/L NS. Hal ini sesuai dengan penelitian yang dilakukan oleh Fernanda, dkk pada tahun 2013 menyatakan bahwa terdapat perbedaan jumlah pasien berdasarkan jenis kelamin dan jenis pada CB, namun tidak didapatkan hubungan antara jenis kelamin dan jenis celah bibir dengan nilai signifikansi 0,216 $\quad(p>0,05)(8)$. Penelitian sebelumnya yang dilakukan oleh YokikazhuNagase, dkk pada tahun 2010 menyatakan bahwa jenis kelamin memiliki hubungan yang signifikan mengenai pada jenis atau tipe celahnya $(\mathrm{CB}, \mathrm{CB} / \mathrm{L}, \mathrm{SL})$, namun tidak memiliki hubungan yang signifikan terhadap gambaran klinis pada kelainan tersebut baik letak celahnya (unilateral atau bilateral) maupun luas celahnya (komplit atau inkomplit)(9).

Hasil penelitian ini berbanding terbalik dengan penelitian yang dilakukan oleh Daniella R. B. Martelli, dkk pada tahun 2012 yang menyebutkan bahwa terdapat hubungan yang signifikan antara jenis kelamin dan jenis atau tipe celahnya. Hal ini dikarenakan penelitian tersebut menggunakan skrining langsung terhadap pasien $\mathrm{CB} / \mathrm{L}$ NS untuk menilai adanya sindrom atau kelainan lain yang menyertai serta menilai langsung morfologi dari jenis celah yang dialami pasien pada 366 sampel di Brazil dari tahun 2009-2011. Penelitian tersebut juga memonitor faktor-faktor lainnya yang dapat mempengaruhi kejadian CB/L NS seperti riwayat keluarga dan etnis(10).

Prevalensi $\mathrm{CB}$ dan $\mathrm{CB} / \mathrm{L}$ NS paling banyak dialami oleh laki-laki(5,7). Prevalensi gambaran klinis menurut letak celahnya paling banyak yakni unilateral. Prevalensi gambaran klinis yang paling banyak menurut luas celahnya yakni komplit(3,5,7). Prevalensi gambaran klinis yang paling banyak yakni celah bibir dengan CBL unilateral komplit(5). Hal ini sesuai dengan prevalensi pasien CB/L NS yang didapatkan dari CLP Center FK UMM periode 2016-2017 pada penelitian ini.

\section{DAFTAR PUSTAKA}

1. Kawalec A, Nelke K, Pawlas K, Gerber $\mathrm{H}$. Risk factors involved in orofacial cleft predisposition-review. Open Med. 2015;10(1):163-75.

2. Murthy J, Bhaskar L. Current concepts in genetics of nonsyndromic clefts. Indian J Plast Surg [Internet]. 2009;42(1):68. Available from: http://www.ijps.org/text.asp?2009/42/1 /68/53004

3. Mossey PA, Little J, Munger RG, Dixon MJ, Shaw WC. Cleft lip and palate. Lancet. Elsevier Ltd; 2009;374(9703):1773-85.

4. 1 Scheller K, Kalmring F, Schubert J. Sex distribution is a factor in teratogenically induced clefts and in the anti-teratogenic effect of thiamine in mice, but not in genetically determined cleft appearance. J Cranio-Maxillofacial Surg [Internet]. Elsevier Ltd; 2016;44(2):104-9. Available from:

http://dx.doi.org/10.1016/j.jcms.2015.1 0.025

5. Moreira HSB, Machado RA, de Aquino SN, Rangel ALCA, Júnior HM, Coletta $\mathrm{R}$ Della. Epidemiological features of patients with nonsyndromic cleft lip and/or palate in Western Parana. Brazilian J Oral Sci. 2016;15(1):39-44.

6. Kosowski TR, Weathers WM, Wolfswinkel EM, Ridgway EB. Cleft Palate. 2012;1(212):164-9. 
7. Riana R. Distribusi Sumbing Bibir Dan Langit-Langit Di Cleft Lip and Palate Center Fakultas Kedokteran Universitas Muhammadiyah Malang Indonesia. Saintika Med. 2016;11(2):76-7.

8. Dornelles F, Cuozzo M, Espinosa MM, Tavares K. Cleft lip and palate in a Brazilian subpopulation Cleft lip and palate in a Brazilian subpopulation. J Int Oral Heal. 2013;5(4):15-20.

9. Lipinski RJ, Holloway HT, O'LearyMoore SK, Ament JJ, Pecevich SJ, Cofer GP, et al. Characterization of subtle brain abnormalities in a mouse model of hedgehog pathway antagonist-induced cleft lip and palate. PLoS One. 2014;9(7):3-9.

10. Martelli DRB, Machado RA, Swerts MSO, Rodrigues LAM, de Aquino SN, Martelli Júnior $H$. Non sindromic cleft lip and palate: Relationship between sex and clinical extension. Braz J Otorhinolaryngol [Internet]. AssociaÃß Âfo Brasileira de Otorrinolaringologia e Cirurgia CÃCrvico-Facial; $\quad$ 2012;78(5):116-20. Available from: http:/ /dx.doi.org/10.5935/18088694.20120018

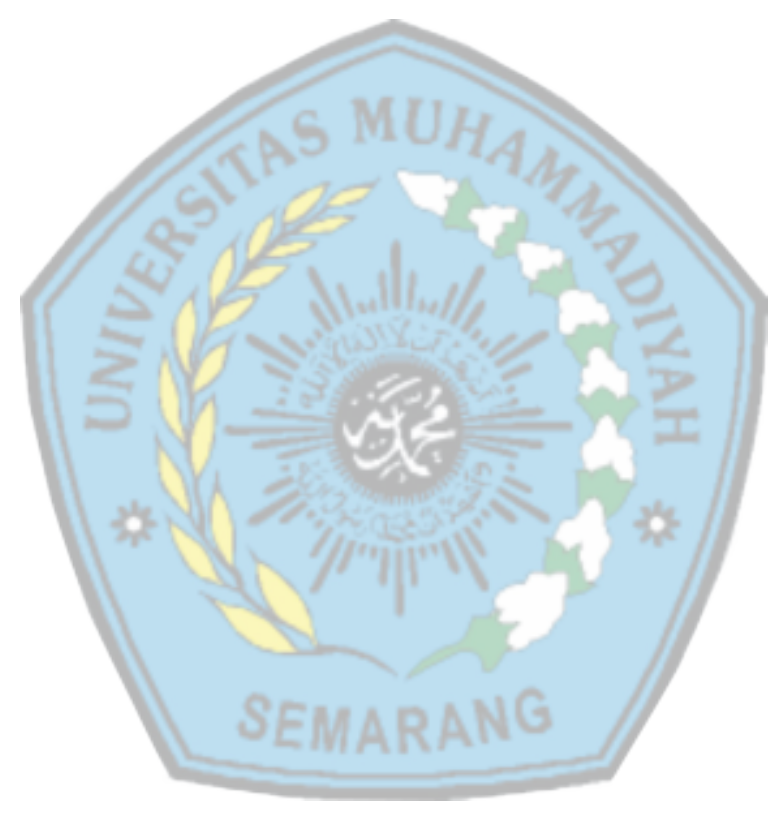

